\title{
PENGEMBANGAN MODUL PERUBAHAN LINGKUNGAN DAN DAUR ULANG LIMBAH BERBASIS DISCOVERY LEARNING MELALUI MEDIA GOOGLE CLASSROOM
}

\section{DEVELOPMENT OF ENVIRONMENTAL CHANGE AND WASTE RECYCLING MODULES BASED ON DISCOVERY LEARNING THROUGH GOOGLE CLASSROOM MEDIA}

\author{
Ainul Muttaqin*, Achmad Noor Fatirul, Hartono \\ Program Studi Teknologi Pendidikan, Program Pascasarjana Universitas PGRI Adi Buana Surabaya, Indonesia \\ *Email: ainul@smam1gresik.sch.id
}

Diterima: 17 Juli 2019. Disetujui: 17 Juli 2019. Dipublikasikan: 31 Juli 2019

\begin{abstract}
Abstrak: Pembelajaran biologi lebih diorientasikan pada pembelajaran yang mengutamakan pengalaman belajar bagi peserta didik. Hal ini bisa diperoleh melalui rangkaian kegiatan interaksi aktif teman sejawat dan lingkungan belajar peserta didik. Pembelajaran biologi perlu dikembalikan pada pembelajaran yang sebenarnya yaitu pendekatan produk dan proses pembelajaran dengan cara melibatkan secara aktif seluruh peserta didik dalam mengelola serta mengembangkan keterampilan berfikir kritis, keterampilan proses, mengembangkan pengetahuan maupun pengalaman peserta didik seperti pengembangan pembelajaran berbasis discovery learning. Tujuan penelitian pengembangan ini adalah untuk mengetahui tingkat karakteristik, kelayakan dan keefektifan modul pembelajaran biologi berbasis Discovery Learning pada materi perubahan lingkungan dan daur ulang limbah sesuai dengan kebutuhan peserta didik di kelas X SMA Muhammadiyah 1 Gresik melalui media google classroom. Dalam pengembangan produk ini menggunakan teori Borg and Gall yang terdiri dari (1) Penelitian pendahuluan dalam rangka mengidentifikasi masalah dan potensinya. (2) Proses pengumpulan data. (3) Pembuatan desain produk. (4) Validasi desain. (5) Revisi desain. (6) Uji coba produk. (7) Revisi produk. Sedangkan model pengembangannya menggunakan model pengembangan produk diadaptasikan dari model ADDIE, yaitu Analyze, Design, Develop, Implement and Evaluate. Berdasarkan pada hasil data kajian analisis yang diuraikan sebelumnya, dapat disimpulkan bahwa produk pengembangan modul pembelajaran biologi SMA kelas X pada materi perubahan lingkungan dan daur ulang limbah sangat layak untuk diaplikasikan dalam pembelajaran pada peserta didik SMA Muhammadiyah 1 Gresik. Dasar kelayakan ini diambil dari hasil penilaian para ahli baik ahli media, ahli isi materi, dan penilaian teman sejawat. Selain memang layak, modul ini dikembangkan menggunakan pendekatan pembelajaran discovery learning dan dilakukan melalui aplikasi online google classroom dengan tujuan utama adalah pembelajaran yang aktif dan kreatif dari peserta didik.
\end{abstract}

Kata Kunci: modul, biologi, perubahan lingkungan, daur ulang limbah, discovery learning, google classroom.

\begin{abstract}
A problem-based biological learning approach able to provide a complete experience in understanding the concept of learning. Especially in material about environmental damage, students need to explore directly the potentials around them. By understanding the potential that exists, students can analyze opportunities for damage and try to make preventive steps. The purpose of this development research is to determine the level of characteristics, feasibility and effectiveness of biology learning modules based on Discovery Learning on environmental change material and waste recycling according to the needs of students through google classroom media. In developing this product using the Borg and Gall theory which consists of (1) preliminary research in order to identify the problem and its potential. (2) The process of collecting data. (3) Making product design. (4) Design validation. (5) Design revisions. (6) Test the product. (7) Product revision. While the development model uses a product development model adapted from the ADDIE model, namely Analyze, Design, Develop, Implement and Evaluate. Based on the results of the analysis study data described earlier, it can be concluded that the product development of class X high school biology learning modules on material changes in the environment and waste recycling is very feasible to be applied in learning to students of Muhammadiyah 1 Gresik High School. The basis of this feasibility is taken from the results of the assessment of experts both media experts, material content experts, and peer assessments. Besides being feasible, this module was developed using the discovery learning approach and carried out through google classroom online applications with the main goal being active and creative learning from students.
\end{abstract}

Keywords: Modules, Biology, Environmental Change, Waste Recycling, Discovery Learning, Google Classroom.

\section{PENDAHULUAN}

Pola pendekatan pembelajaran yang inovatif dan berbasis pada kreativitas peserta didik menjadi sebuah keniscayaan. Pembelajaran dalam ilmu sains, khususnya mata pelajaran biologi harus dengan pendekatan saintifik seperti amanah dalam kurikulum 
2013. Dimana pola yang dilakukan dalam pendekatan saintifik ini mengutamakan pada keaktifan peserta didik dalam mencari dan mengelola pengetahuan yang diperolehnya.

Belajar diartikan sebagai suatu proses yang dilakukan oleh individu untuk memperoleh perubahan perilaku baru secara keseluruhan, sebagai hasil dari pengalaman individu itu sendiri dalam berinteraksi dengan lingkungannya [1]. Selain itu belajar merupakan proses di mana tingkah laku (dalam arti luas) ditimbulkan atau diubah melalui praktek atau latihan) [2]. Sehingga dalam pembelajaran yang dilakukan sudah seharusnya mengarah pada perubahan tingkah laku dari peserta didik melalui pengalaman yang didapatkannya.

Aktivitas industri di Gresik memiliki keragaman yang cukup banyak. Daya dukung infrastruktur menjadi alasan kuat berdirinya kawasan industri di Gresik. Selain itu tersedianya daya dukung sumber daya alam maupun manusia yang memadai. Walaupun ada beberapa dampak yang menyertai dari eksplorasi dan eksploitasi sumber daya alam sebagai bahan baku industri.

Pemanfaatan sumber daya alam sebagai bahan baku industri dilakukan oleh aktivitas utama industri di Gresik. Kapur misalnya digunakan sebagai bahan baku utama semen [3]. Selain itu kapur juga digunakan sebagai bahan baku pupuk [4]. Namun dari aktivitas tersebut yang sangat kelihatan jelas dampaknya adalah terdapatnya lubang tanah yang sangat besar dan juga berkurangnya lapisan pegunungan kapur. Dampak dari aktivitas ini yang menjadi masalah adalah hilangnya potensi kapur karst sebagai penahan air tanah dan tidak adanya upaya recovery bekas galian ini sehingga pertambangan kapur karst tidak hanya memiliki dampak bencana namun juga dampak sosial ekonomi [5].

Dampak yang terjadi adalah ketidakseimbangan ekosistem lingkungan di Gresik. Potensi pencemaran udara, pencemaran air, meningkatnya iklim, berkurangnya air tanah, dan beberapa penyakit menjadi kerisauan banyak pihak khususnya masyarakat Gresik. Ditambah lagi dengan minimnya ruang terbuka hijau semakin mendukung rusaknya lingkungan di Gresik.

Permasalahan lingkungan yang telah diuraikan diatas masih juga menyisakan permasalahan pada pengelolaan budaya peduli lingkungan khususnya didalam pembelajaran. Pada pembelajaran disekolah masih minim modul pembelajaran yang mengajak peserta didik berperan aktif dalam pembelajaran, sekaligus belum menghasilkan pembiasaan budaya bersih pada warga sekolah.

Melihat kebutuhan yang sangat mendesak tentang pentingnya peran pendidikan dalam mempengaruhi ada dan tidaknya pencemaran lingkungan, maka perlu ada pendekatan pembelajaran materi perubahan lingkungan. Materi perubahan lingkungan masuk dalam mata pelajaran biologi kelas
X peminatan MIPA. Dalam banyak hal materi perubahan lingkungan masih menggunakan pendekatan global dan belum menyentuh pada perubahan lingkungan yang menjadi masalah di sekitar peserta didik. Sehingga pada materi perubahan lingkungan ini hanya sebatas pada hafalan bukan pemahaman yang dirasakan secara utuh oleh peserta didik. Model pembelajaran discovery learning dipilih dalam penyusunan bahan ajar ini agar mampu meningkatkan kompetensi peserta didik pada mata pelajaran biologi yang ditunjukkan oleh aspek-aspek kognitif, afektif, dan psikomotorik selama kegiatan pembelajaran melalui proses penemuan. Model discovery learning memberikan pengaruh yang signifikan daripada pembelajaran konvensional dalam meningkatkan hasil belajar peserta didik [6].

\section{METODE PENELITIAN}

Penelitian ini dilakukan di SMA Muhammadiyah 1 Gresik Jawa Timur pada semester gasal tahun pelajaran 2018/2019.

Dalam penelitian dan pengembangan ini kami adaptasikan dari teori Borg and Gall yang terdiri dari: 1)Penelitian pendahuluan dalam rangka mengidentifikasi masalah dan potensinya. 2)Proses pengumpulan data. 3)Pembuatann desain produk. 4)Validasi desain. 5)Revisi desain. 6)Uji coba produk. 7)Revisi produk. 8)Uji coba pemakaian. 9)Revisi produk akhir. Dan 10)Penyebaran dan implementasi. Dari model diatas, diadaptasi hanya sampai 7 (tujuh) langkah sebagai proses dalam pengembangan atau validasi produk-produk yang digunakan pada proses pembelajaran.

Model pengembangan produk diadaptasikan dari model ADDIE, yaitu Analyze, Design, Develop, Implement and Evaluate. Penggunaan ADDIE karena memiliki prosedur kerangka kerja yang tepat dalam mengembangkan produk pendidikan dan sumber belajar.

Penelitian pengembangan ini menggunakan metode metode wawancara, dan metode observasi. Teknik pengumpulan data dalam kegiatan pembelajaran. Sumber data dalam penelitian ini yaitu: data penilaian kelayakan modul oleh pakar menggunakan instrumen berupa angket yang berisi penilaian terhadap kelayakan modul yang dikembangkan, data tanggapan penggunaan modul oleh guru dan peserta didik berupa angket, dan data hasil hasil wawancara yang dilakukan dengan metode triangulasi kepada ahli materi, guru, dan peserta didik.

\section{HASIL DAN PEMBAHASAN}

Kajian Produk Pengembangan

1. Identitas Produk
a. Bentuk Modul
b. Format
c. Judul



d. Pengguna
e. Nama Pengarang
: Kelas X MIPA SMA
f. Ketebalan
Muhammadiyah 1 Gresik
g. Cetakan
: Ainul Muttaqin
: 70 halaman
h. Ukuran Kertas
: Pertama
: A4

2. Karakteristik dan Analisis Produk

a. Link Program Online

Pada modul pembelajaran biologi materi perubahan lingkungan dan daur ulang limbah sengaja dimasukkan dalam fasilitas aplikasi yang dimiliki oleh

b. Tampilan Aplikasi Google Classroom

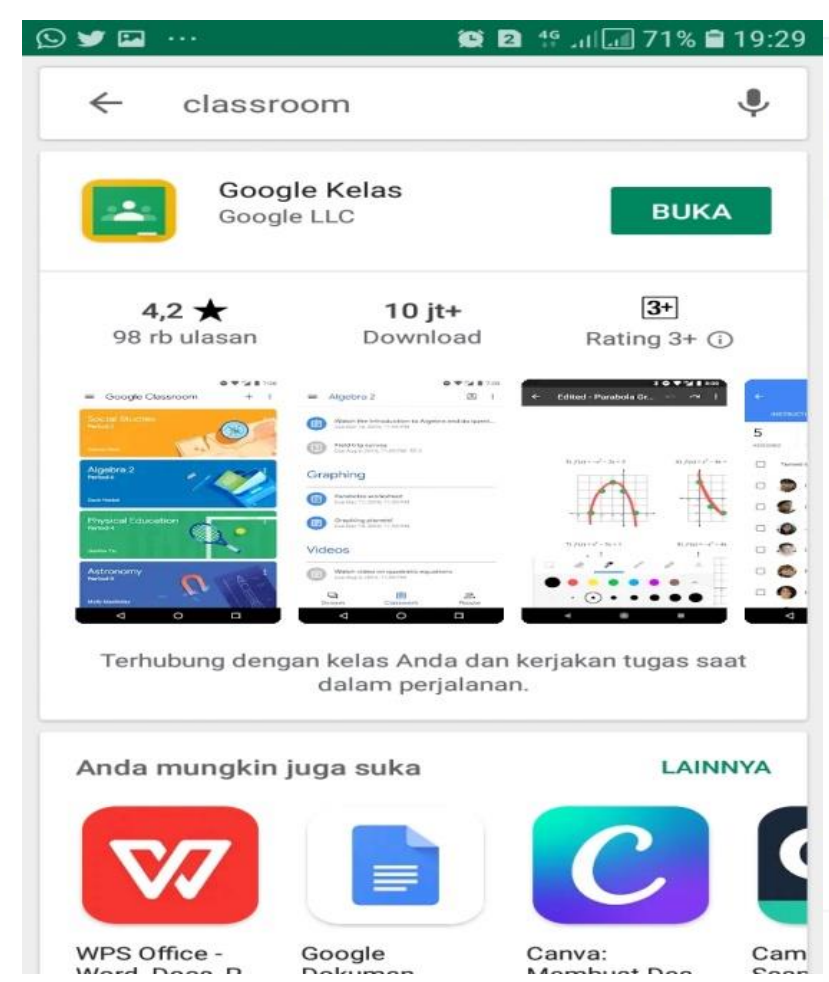

google yaitu google classroom. Dalam aplikasi ini bisa didownload di Play Store dengan aplikasi google classroom pada android atau bisa langsung masuk di google jika menggunakan komputer melalui link https://classroom.google.com.

Pada kelas ini lebih mengutamakan pada proses pembelajaran secara daring baik dilakukan disekolah atau melalui kesepakatan diluar jam sekolah. Sehingga interaksi yang dilakukan bisa berlangsung secara online baik dalam belajar dan melakukan chatting maupun dalam hal penugasan dan ulangan.

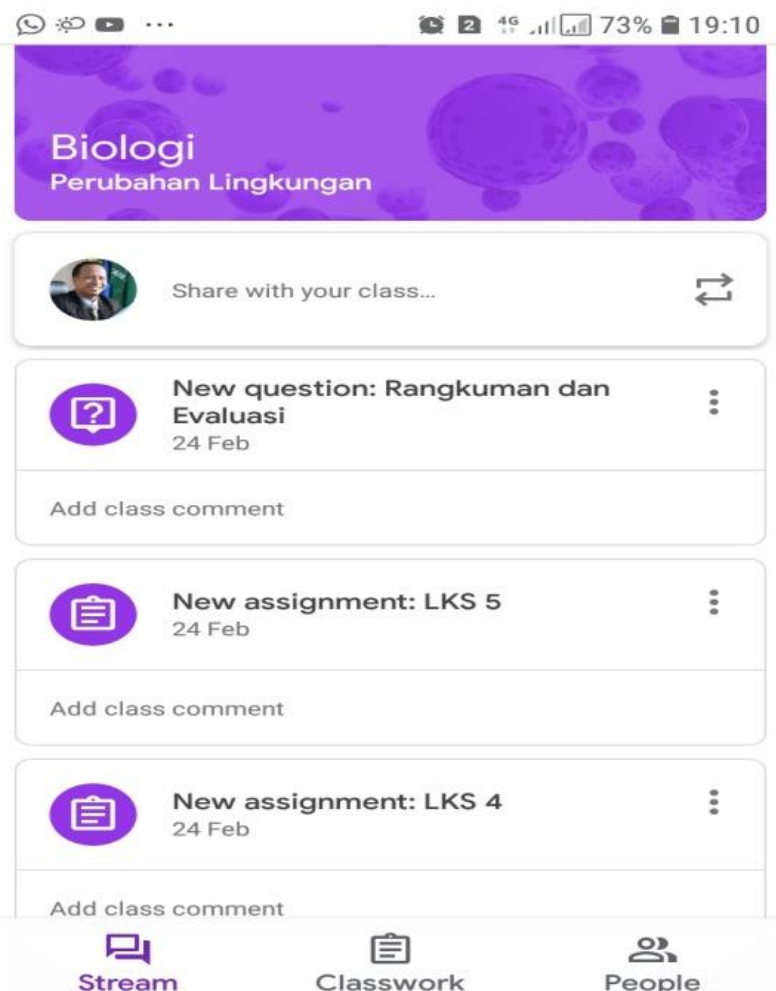

Gambar 1. Tampilan Aplikasi Google Classroom

Gambar 1 menunjukkan tampilan aplikasi google classroom pada playstore serta tampilan menu kerja. Dalam menu ini guru maupun peserta didik bisa mengakses sesuai yang sudah diatur oleh guru selaku operator.

Pada modul pembelajaran biologi yang dikembangkan melalui media google classroom difasilitasi berupa pembuatan kelas, mendistribusikan tugas, memberi nilai, mengirim masukan, dan melihat semuanya hanya melalui satu aplikasi. Sehingga kemudahan dan efektivitas pembelajaran sampai dengan evaluasi bisa dilakukan. Selain itu secara strategi pendekatan kognitif bisa memfasilitasi peserta didik untuk melakukan pengulangan pembelajaran dengan cara mengakses kelas di google classroom.

\section{Hasil Produk dan Analisis Data \\ 1. Analisis Data Ahli Media}

Hasil penilaian ahli media diperoleh data hitungan persentase dapat dilihat pada Gambar 2. 


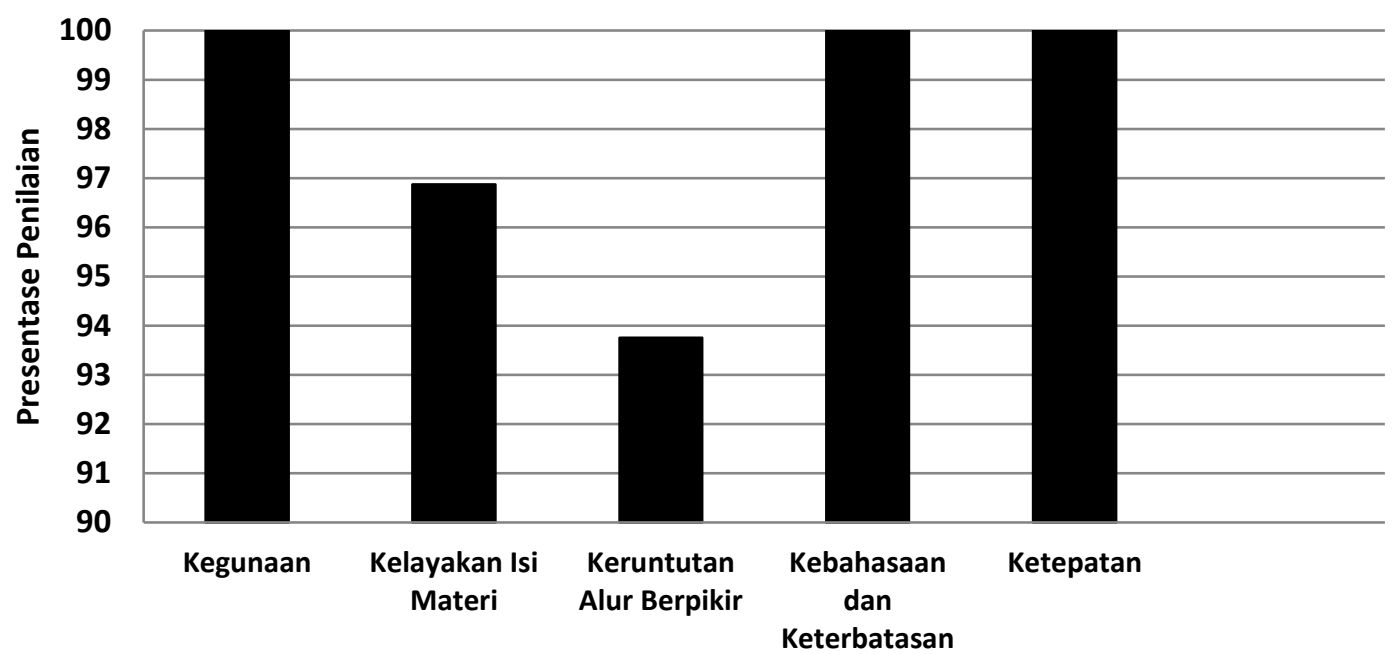

Gambar 2. Persentase Penilaian Data Ahli Media

Data yang ditunjukkan oleh Gambar 2 tentang persentase penilaian data ahli media menunjukkan nilai rata-rata diatas $93 \%$ yang artinya masuk dalam kategori sangat baik dan tidak perlu ada revisi.
2. Analisis Data Ahli Isi Materi

Hasil penilaian ahli isi materi diperoleh data hitungan persentase dapat dilihat pada Gambar 3.

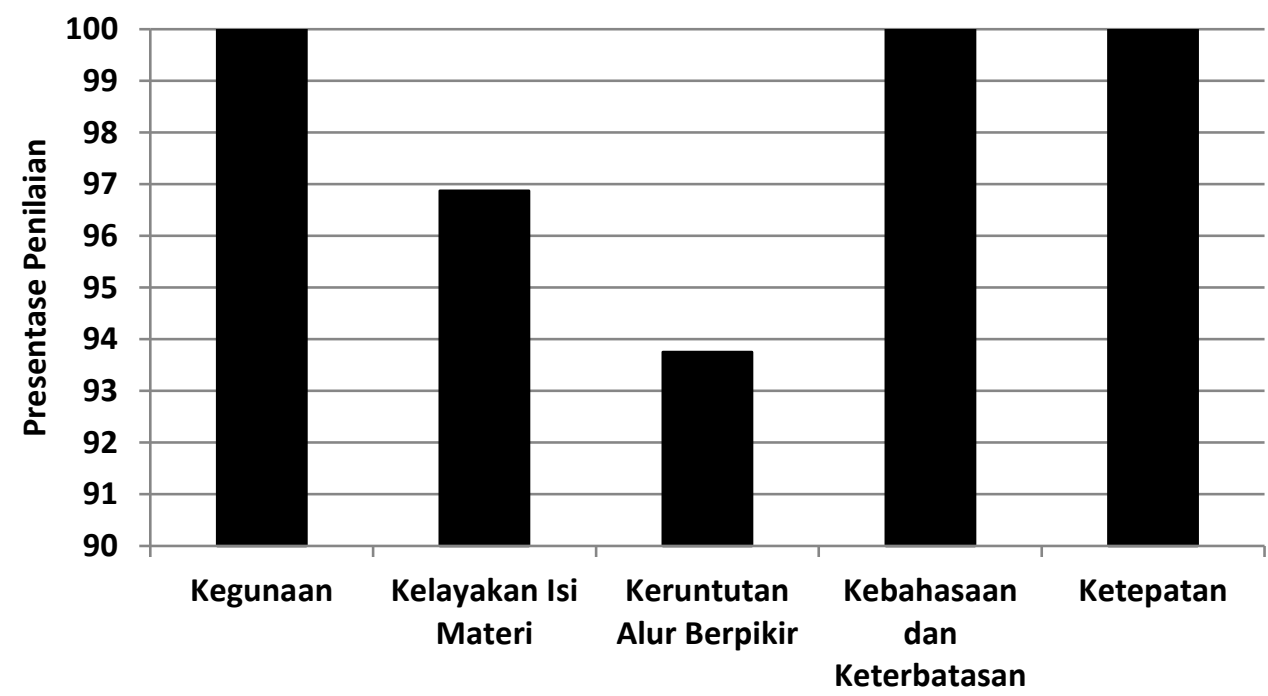

Gambar 3. Persentase Penilaian Data Ahli Isi Materi

Data yang ditunjukkan oleh Gambar 3 tentang persentase penilaian data ahli isi materi menunjukkan nilai rata-rata diatas $93 \%$ artinya penilaian produk sangat baik dan tidak perlu dilakukan revisi.
3. Analisis Data Teman Sejawat

Hasil penilaian teman sejawat diperoleh data hitungan persentase sebagai berikut: 


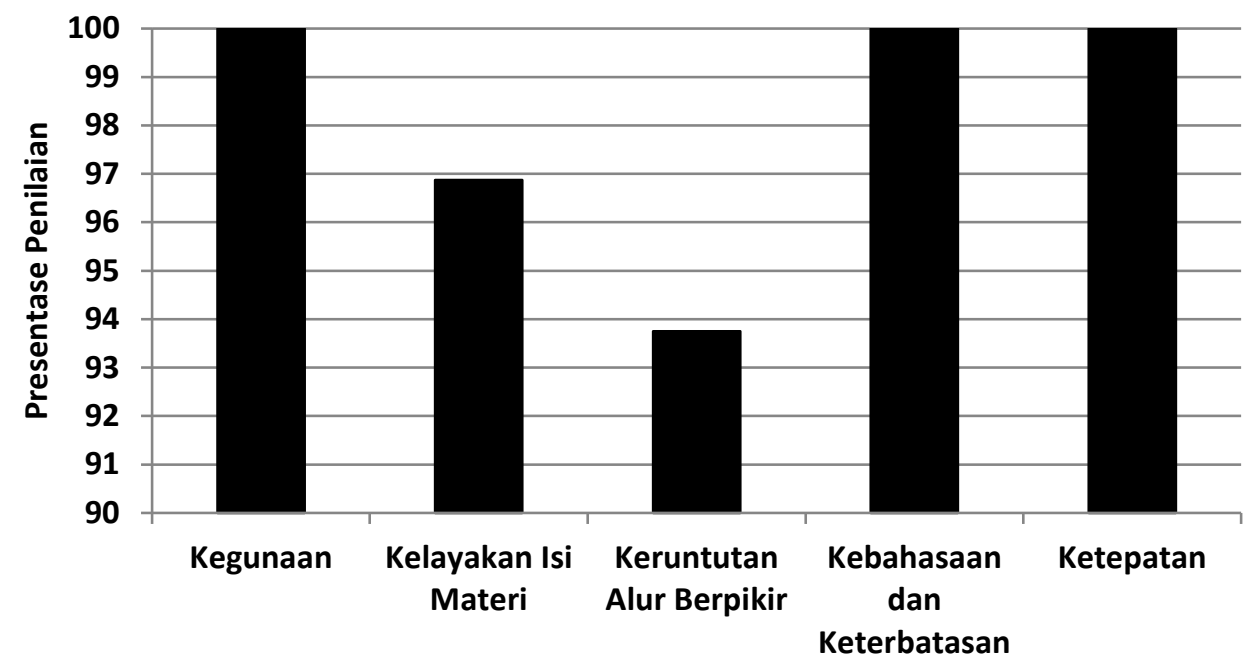

Gambar 4. Persentase Penilaian Data Teman Sejawat

Dari data yang ditunjukkan oleh Gambar 4 tentang persentase penilaian data teman sejawat juga menunjukkan nilai sangat baik dengan perolehan rata-rata nilai diatas $93 \%$ sehingga tidak perlu ada revisi pada produk.
4. Analisis Data Penilaian Peserta Didik

Hasil penilaian Peserta didik diperoleh data dan hitungan persentase dapat dilihat pada Tabel 5.

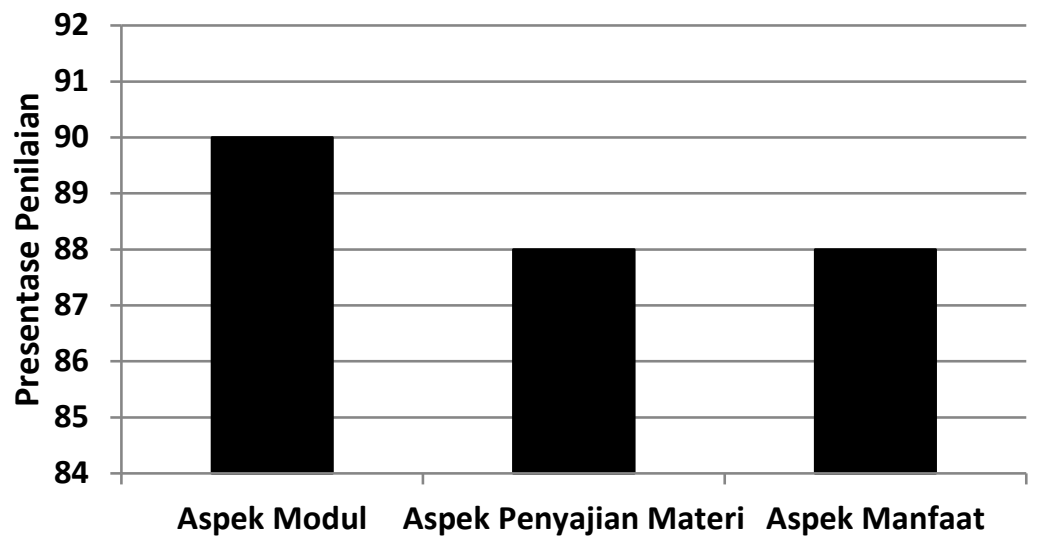

Gambar 5. Persentase Penilaian Peserta Didik

Dari data Gambar 5 terlihat data hasil penilaian peserta didik. Pada aspek modul terlihat paling tinggi pada angka 90\%, sedangkan aspek materi dan manfaat mendapat hasil $88 \%$. Secara umum aspek modul seperti tampilan huruf dan gambar sudah sangat layak. Pada aspek penyajian materi seperti isi materi dan penugasan juga bisa dikatakan sangat layak. Termasuk sisi manfaat modul ini juga sangat layak. Meskipun masih harus ada perbaikan pada beberapa aspek.

\section{Hasil dan Analisis Wawancara Uji Modul}

1. Hasil dan Analisis Wawancara Peserta Didik
Hasil wawancara pada peserta didik seperti yang ditampilkan menunjukkan hasil positif. Pada pertanyaan tentang kendala yang menjadi permasalahan pada pembelajaran materi ini dari semua responden menjawab kendala yang selama ini dirasakan adalah pada metode pembelajaran yang monoton, sumber ajar yang tidak update, dan penjelasan yang kurang detail. Pada pertanyaan kedua tentang pendapat responden mengenai modul berbasis online adalah dari semua responden, $80 \%$ responden menyatakan sangat membantu, sedang $20 \%$ responden menjawab cukup membantu. Pada pertanyaan ketiga tentang kontribusi modul pada pembelajaran adalah dari semua responden semuanya menjawab lebih semangat belajar, lebih 
mudah dalam memahami materi, dan lebih mudah berkonsultasi dengan guru. Dan pada pertanyaan keempat tentang hal-hal yang perlu diperbaiki pada modul ini adalah $40 \%$ responden menjawab tidak perlu ada perbaikan, kemudian $40 \%$ responden lagi menjawab perlu komunikasi yang efektif antara guru dan peserta didik serta perlu terus diupdate informasi tentang materi, dan $20 \%$ responden menjawab perlunya guru meningkatkan kemampuan penguasaan teknologi digital dan perlu update informasi tentang materi. Dari hasil wawancara diatas bisa dianalisis bahwa peserta didik bisa menerima dengan baik modul yang dikembangkan ini.

\section{Hasil dan Analisis Wawancara Guru}

Hasil wawancara pada guru juga menunjukkan hasil positif pada modul ini. Responden diambil 2 (dua) guru mata pelajaran biologi SMA Muhammadiyah 1 Gresik Pada pertanyaan tentang hasil pembelajaran materi ini sebelum dilakukan uji produk modul hasilnya relatif cukup baik bahkan cenderung kurang baik. Pada pertanyaan kedua dari kedua responden menyatakan bahwa kendala utama dalam pembelajaran materi ini adalah lemahnya pemahaman peserta didik pada konsep yang diberikan, tidak memiliki bahan ajar yang sesui dengan kondisi terdekat dengan peserta didik, dan padatnya struktur kurikulum.Pada pertanyaan ketiga didapatkan jawaban bahwa modul ini sudah menggambarkan pembelajaran berbasis discovery learning. Pada pertanyaan keempat kedua responden menyatakan modul berbasis online ini sangat membantu dalam pembelajaran. Pada pertanyaan kelima responden menyatakan bahwa modul yang dibuat bisa membantu pada aspek keaktifan peserta didik dalam pembelajaran, pemahaman peserta didik, ketertarikan peserta didik dalam belajar. Dan ketercapaian hasil evaluasi pembelajaran. Dan pada pertanyaan keenam responden menyatakan bahwa yang perlu diperbaiki pada modul ini adalah kemampuan guru dalam menguasai teknologi digital, komunikasi yang efektif antara guru dan peserta didik, dan Update data dan informasi dari guru kepada peserta didik.

Dari hasil wawancara guru diatas secara umum bisa dianalisis bahwa modul ini sangat membantu guru dalam pembelajaran.

\section{Hasil dan Analisis Wawancara Ahli Materi}

Hasil wawancara ahli materi menunjukkan hasil yang positif. Pada pertanyaan pertama responden menyatakan bahwa modul sudah sangat sesuai dengan tujuan pembelajaran. Pada pertanyaan kedua responden menyatakan bahwa modul ini juga sudah sangat sesuai dengan kaidah discovery learning. Pada pertanyaan ketiga responden menyatakan bahwa modul berbasis online yang dikembangkan sudah sangat baik. Pada pertanyaan keempat responden menyatakan bahwa modul ini akan membantu dalam keaktifan peserta didik dalam pembelajaran, pemahaman peserta didik, ketertarikan peserta didik dalam belajar, dan ketercapaian hasil evaluasi pembelajaran. Dan pada pertanyaan kelima responden juga menyatakan bahwa hal yang perlu diperbaiki adalah kemampuan guru dalam menguasai teknologi digital, komunikasi yang efektif antara guru dan peserta didik, dan update data dan informasi dari guru kepada peserta didik.

Dari hasil wawancara ahli materi ini dapat dianalisis bahwa ahli materi menyatakan bahwa modul ini sudah sangat layak untuk digunakan. Pola pembelajaran yang dilakukan di SMA Muhammadiyah 1 Gresik secara umum masih menggunakan metode kelas konvensional. Namun sejak tiga tahun terakhir sejak SMA Muhammadiyah 1 Gresik menjadi bagian dari kerjasama dengan google dalam kegiatan google for education dimana disalah satu programnya adalah google classroom maka beberapa mata pelajaran sudah menggunakan fasilitas ini. Meskipun menu google classroom sekarang sudah bisa diakses oleh siapapun . dalam obeservasi yang penulis lakukan ada efektivitas pembelajaran yang dilakukan secara daring ini.

Pengembangan modul dalam pembelajaran biologi menjadi satu terobosan yang dilakukan di SMA Muhammadiyah 1 Gresik yang selama ini masih menggunakan buku paket sebagai pegangan guru maupun peserta didik. Dalam pengembangan modul ini selain bisa memiliki produk dari internal juga tentu labih bisa memfasilitasi local wishdom yang ada di SMA Muhammadiyah 1 Gresik. Bahan ajar terdiri dari pengetahuan (fakta, konsep, prinsip, dan prosedur), keterampilan, dan sikap. Kegiatan belajar mengajar akan menyenangkan peserta didik apabila guru mampu memilih jenis pendekatan dan model pembelajaran dengan tepat. Penerapan pendekatan ilmiah (scientific approach) dalam kegiatan pembelajaran, akan menjadikan pembelajaran berpusat pada peserta didik [7] dan hasil belajar biologi peserta didik lebih tinggi atau lebih baik dibandingkan dengan model pembelajaran langsung [8].

Pembelajaran berbasis discovery learning mampu meningkatkan tingkat kekritisan peserta didk dibandingkan dengan pembelajaran secara konvensional [9]. Kemampuan kognitif peserta didk juga meningkat atau lebih baik daripada pengajaran dengan menggunakan pembelajaran konvensional. Ada perbedaan yang signifikan terhadap peserta didk yang diperlakukan dengan discovery learning dan tidak. Perbedaan tersebut terdapat pada prestasi akademik dan tingkat afektif [10]. Discovery learning mampu meningkatkan pencapaian prestasi dan kemampuan metakognitif. Metakognitif adalah kemampuan peserta didk yang bisa mengendalikan 
area atau sisi kognitif [11]. Metakognitif mengontrol enam jenjang aspek kognitif yang didefinisikan oleh Benjamin Bloom dalam taksonomi Bloom. Jenjang aspek kognitif tersebut adalah: tahap ingatan, pemahaman, terapan, analisis, sintetis dan evaluasi. Discovery learning juga berhubungan dengan aspek komunikasi. Terdapat 3 aktivitas komunikasi yang akan menghasilkan hipotesis, desain penelitian, dan membangun kesimpulan [12]. Discovery learning berkolerasi positif dengan aktivitas komunikasi. Selain itu Pembelajaran model discovery bisa meningkatkan hasil belajar peserta didik [13].

Meskipun modul ini belum sampai pada uji lapangan, namun gambaran ahli dan uji pada teman sejawat serta kelompok kecil peserta didik terpilih dalam penilaiannya terhadap modul sudah mewakili optimisme penggunaan produk modul ini. Kemampuan berfikir peserta didik akan lebih meningkat menggunkan model discovery dibandingkan dengan model lainnya [14]. Apalagi jika melihat model pembelajaran modul ini dilakukan melalui aplikasi gratis seperti google classroom ini bisa memberikan kontribusi yang baik bagi pembelajaran. Setidaknya bagi upaya diferensiasi model pembelajaran pada era revolusi industri 4.0 seperti sekarang ini.

Dalam penerapan pembelajaran melalui google classroom tentu juga menghadapi kendala. Kendala terbesar yang muncul adalah kurang semangatnya guru dalam mendesain bahan ajar yang akan di upload melalui google classroom ini. Karena selama ini memang guru dinina bobokan oleh model pembelajaran yang tidak perlu membuat bahan untuk persiapan pembelajaran seperti metode ceramah.

Khusus tentang modul yang dikembangkan bahwa modul ini benar-benar didesain sesuai karakteristik peserta didik di SMA Muhammadiyah 1 Gresik. Pendekatan pada masalah yang ada disekitar peserta didik seperti kajian limbah industri, limbah rumah tangga, dan limbah wilayah pesisir akan mudah dipahami oleh peserta didik. Modul ini ingin menjawab tentang materi lingkungan hidup yang tidak menyentuh peserta didik sekaligus belum mampu menciptakan kemandirian akan gerakan peduli lingkungan baik secara individu maupun secara kelompok. Modul biologi menggunakan metode discovery learning dengan memanfaatkan potensi lokal mampu meningkatkan hasil belajar peserta didik sebanyak $92 \%$ dibandingkan pada kelas non perlakuan modul yang hanya tuntas $75 \%$ [15].

Modul yang telah melalui tahapan validasi ini tentu bisa memberikan harapan besar bagi model pembelajaran peduli lingkungan diwilayah pesisir seperti diwilayah garis utara kabupaten Gresik. Garis utara Gresik memiliki karakteristik yang kuat pada aktivitas laut dan industri berat. Sehingga dengan modul yang dikembangkan dan didukung dengan pola pembejalaran yang kekinian serta melalui pendekatan saintifik berbasis discovery learning ini maka akan bisa membentuk karakter peduli lingkungan pada warga SMA Muhammadiyah 1 Gresik khususnya pada peserta didiknya. Keterlaksanaan pembelajaran menggunakan modul pembelajaran berbasis saintifik terlaksana dengan baik dan peserta didk terlibat aktif dalam pembelajaran [16]. Perolehan respon peserta didk terhap modul pembelajaran dengan persentase ratarata kategori kuat dan kuat adalah $84,23 \%$ dan respon guru sebesar $88,7 \%$ sehingga dapat disimpulkan respon peserta didk dan guru adalah positif.

Selain itu dalam modul yang dibuat dikembangkan menggunakan pendekatan discovery learning. Pada pola pendekatan ini tujuan utamanya adalah pada pendekatan student center dimana pola pendekatannya adalah membimbing peserta didik menjadi lebih aktif dalam menemukan konsep dan menemukan pengetahuannya secara mandiri meskipun dilakukan secara berkelompok. Selain itu peserta didik diajak untuk memahami konsep metode ilmiah melalui percobaan yang dilakukan. Peserta didik juga sudah mulai diajak meninggalkan model hafalan, namun sudah mulai pada konsep menganalisis dan mengkreasikan menjadi produk unggulan baru. Disamping proses pembelajarannya, peserta didik juga dilatih untuk melakukan komunikasi baik secara tulisan maupun presentasi secara lisan.

\section{KESIMPULAN}

Berdasarkan pada hasil data kajian analisis yang diuraikan sebelumnya, dapat disimpulkan bahwa produk pengembangan modul pembelajaran biologi SMA kelas $\mathrm{X}$ pada materi perubahan lingkungan dan daur ulang limbah sangat layak untuk diaplikasikan dalam pembelajaran pada peserta didik SMA Muhammadiyah 1 Gresik. Dasar kelayakan ini diambil dari hasil penilaian para ahli baik ahli media, ahli isi materi, dan penilaian teman sejawat, serta penilaian peserta didik.

Selain memang layak, modul ini dikembangkan menggunakan pendekatan pembelajaran discovery learning dan dilakukan melalui aplikasi online google classroom dengan tujuan utama adalah pembelajaran yang aktif dan kreatif dari peserta didik.

\section{DAFTAR PUSTAKA}

[1] Surya dalam Rusman, Pembelajaran Berbasis Teknologi Informasi dan Komunikasi, Mengembangkan Profesionalitas Guru, Jakarta, Raja Grafindo Persada, 2012: 7.

[2] Howard L. Kingskey dalam Rusman et.al, Pembelajaran Berbasis Teknologi Informasi dan Komunikasi, Mengembangkan Profesionalitas Guru, Jakarta: Raja Grafindo Persada, 2012: 8. 
[3] Ratnanto, F. dan Utama, W.Y, 2014, Optimisasi Tingkat Persediaam Bahan Baku Batu Kapur di PT Semen Indonesia Unit Tuban I, Simposium Nasional Teknologi Terapan (SNTT) 2014, Surakarta, Universitas Muhammadiyah Surakarta

[4] Badan Penyuluhan dan Pengembangan SDM Pertanian Pusat Pelatihan Pertanian, 2015, Pelatihan Teknis Budidaya Jagung Bagi Penyuluh Pertanian dan Babinsa, Jakarta, Pusat Pelatihan Pertanian.

[5] Zuchrufa, M., 18 Oktober 2017, Karst, Kerusakan Lingkungan, dan Kelangsungan Hidup, Pusat Penelitian Kemasyarakatan dan Kebudayaan LIPI.

[6] Ivanto, R. E. (2015). Penerapan model pembelajaran discovery learning pada kurikulum 2013 terhadap hasil belajar passing bawah. Jurnal Pendidikan Olahraga dan Kesehatan, 03(02): 330-336.

[7] Kamaliyah. (2016). Mendesain dan melaksanakan pendekatan ilmiah dalam pembelajaran matematika. Jurnal Pendidikan Matematika, 4(2): 118-125.

[8] Marjan, J., Arnyana, I. B. P, Setiawan, I. G. A. N. (2014). Pengaruh pembelajaran pendekatan saintifik terhadap hasil belajar biologi dan keterampilan proses sains siswa ma mu'allimat nw pancor selong kabupaten lombok timur nusa tenggara barat. e-Journal Program Pascasarjana Universitas Pendidikan Ganesha Program Studi IPA, 4.

[9] Martaida, T., Bukit, N., Ginting, E.M. (2017). The effect of discovery learning model on student's critical thinking and cognitive ability in junior high school. IOSR Journal of Research \& Method in Education, 7(6): 01-08.

[10] Balim, A. G. (2009). The effects of discovery learning on students'success and inquiry learning skills. Eurasian Journal of Educational Research. 35: 1-20.

[11] Mahmoud, A. K. A. (2014). The effect of using discovery learning strategy in teaching grammatical rules to first year general secondary student on developing their achievement and metacognitive skills. International Journal of Innovation and Scientific Research. 5(2): 146-153
[12] Saab, N., Jolingen, W. R. (2005). Communication in collaborative discovery learning. British Journal of Educational Psychology. 75: 603-621.

[13] Mahyaeny, (2016). Peningkatan Hasil Belajar Siswa Melalui Strategi Pembelajaran Discovery Pada Mata Pelajaran Ipa Biologi Kelas Vii-5 SMPN 4 Mataram. Jurnal PIJAR MIPA. Vol 11 (1): 39-46.

[14] Ishak, dkk. (2017). Pengaruh Penerapan Pendekatan Saintifik Menggunakan Model Pembelajaran Discovery Dan Kooperatif Tipe Stad Terhadap Kemampuan Berpikir Kreatif Peserta Didik SDN 13 Ampenan. Jurnal PIJAR MIPA. Vol XII (1): 5-10.

[15] Maflukha, D., dkk., 2017. Pengembangan Modul Biologi Pembelajaran Discovery Learning yang Dipadu Survey Lapangan Dengan Memanfaatkan Potensi Lokal Pada Materi Fungi SMA Kelas X Kurikulum 2013. Jurnal Inkuiri. 6(2): 147-156.

[16] Setiyadi, M.W., dkk. 2017. Pengembangan Modul Pembelajaran Biologi Berbasis Pendekatan Saintifik Untuk Meningkatkan Hasil Belajar Peserta didk. Journal of Educational Science and Technology. 3(2): 102-112. 